Вирста, Н. Б., \& Рокіцька, Н. В. (2020). Основні напрямки дослідження українських прізвищ (кінець XVII - початок XXI ст.): I. Доробок українських ономастів. Studia z Filologii Polskiej i Słowiańskiej, 55, Article 1948. https://doi.org /10.11649/sfps.1948

Vyrsta, N. B., \& Rokits'ka, N. V. (2020). Osnovni napriamky doslidzhennia ukraïns'kykh prizvyshch (kinets' XVII - pochatok XXI st.): I. Dorobok ukraïns'kykh onomastiv. Studia z Filologii Polskiej i Słowiańskiej, 55, Article 1948. https://doi.org /10.11649/sfps.1948

Наталія Богданівна Вирста

(Тернопільський національний педагогічний університет імені Володимира Гнатюка)

Наталія Володимирівна Рокіцька (Тернопільський національний педагогічний університет імені Володимира Гнатюка)

\title{
Основні напрямки дослідження українських прізвищ (кінець XVII - початок XXI ст.): I. Доробок українських ономастів
}

Антропонімія кожного народу є своєрідною скарбницею його історико-культурної спадщини, цінним джерелом для етнографічних, соціокультурних, лінгвістичних, культурологічних студій.

Основним класом антропонімної системи є прізвища, які формувалися на основі власних і загальних назв. Головну роль у цьому процесі відіграли імена та прізвиська, тому вивчення прізвищ передбачає й аналіз цих антропонімів.

This is an Open Access article distributed under the terms of the Creative Commons Attribution 3.0 PL License (creativecommons.org/licenses/by/3.0/pl/), which permits redistribution, commercial and non-commercial, provided that the article is properly cited. (c) The Author(s) 2020.

Publisher: Institute of Slavic Studies, Polish Academy of Sciences

[Wydawca: Instytut Slawistyki Polskiej Akademii Nauk] 
Предметом розгляду статті є основні напрямки дослідження українських прізвищ, зокрема історія їхнього вивчення, лексична база, словотвірна структура і проблеми класифікації. У статті проаналізовано доробок українських ономастів.

Актуальними нині є дослідження регіональної антропонімії, які дають важливий матеріал для діалектології, лексикології, дериватології та інших мовних дисциплін. У власних назвах найповніше сконцентрована лінгвістична та історична інформація про колишні реалії життя народу загалом і конкретного регіону зокрема.

\section{3 історії вивчення українських антропонімів}

Першу принагідну спробу тлумачення онімів, зокрема християнських імен, подано в Лексиконі словенороському Памви Беринди, що вийшов у Києві в 1627 р. Автор свідомо поділив свій словник на дві окремі частини. Перша - Лексикон словенороський - це перекладний словник, що нагадує сучасні диференціальні словники. Друга частина є словником іншомовних слів, загальних назв і власних імен, що вживалися в тогочасній літературі. Цей твір укладений на матеріалах, зібраних переважно самим автором з різних книг, писаних церковнослов’янською мовою.

Спеціальні дослідження з вивчення українських антропонімів з'являються в кінці XIX - на початку XX ст. Це роботи А. Степовича, М. Сумцова, В. Ястребова, В. Охримовича.

3 появою праці І. Франка Причинки до украӥнської ономастики (1905 р.) починається науковий підхід до аналізу українських власних особових назв. Ї̈̈ прийнято вважати першою науковою розгорнутою студією з української антропонімії, у якій автор розглядає двоіменну антропонімійну систему, відзначає, що в українському селі діє принцип дво- і багатоіменності; здійснює класифікацію основних схем родових іменувань, запропонованих М. Сумцовим і В. Охримовичем (Франко, 1986).

У 1929 р. вийшла друком праця В. Сімовича Украйнські йменники чоловічого роду на -о в історичному розвитку й освітленні, у якій мова йде про імена, прізвища, прізвиська та їх відношення до загальних назв (Сімович, 1929).

У 60-70-ті роки ХХ ст. чеські, а згодом польські дослідники почали розглядати ономастику самостійною наукою. Українська антропо- 
німіка саме тоді виходить на новий етап розвитку, виокремившись як окрема галузь ономастики, складна і самостійна мовна система (Енциклопедія українознавства, 1993-2003, т. 5, с. 1679). Поштовхом до грунтовного аналізу українських особових назв стала публікація в 1958 р. праці Л. Гумецької Нарис словотворчої системи української актової мови $X I V-X V \mathrm{~cm}$. (розділ цієї книги «Власні імена людей»), присвяченої вивченню словотвірної структури особових назв, засвідчених у пам'ятках української мови XIV-XV ст. (Гумецька, 1958). Відтоді розпочинається системне і грунтовне наукове вивчення історичного українського антропонімікону; дослідженню українських іменувань присвячені дисертаційні праці, монографії, численні наукові статті багатьох вітчизняних лінгвістів.

Вивчаючи українські власні назви, дослідники багато уваги приділяють питанням формування й розвитку національної антропонімної системи, функціонуванню антропонімів у мові, деривації та семантиці особових назв. Українські власні особові назви на матеріалі всієї етнічної території України вивчали: Ю. Редько (Сучасні українські прізвища), М. Худаш (3 історії української антропонімї), Р. Керста (Українська антропонімія XVI cm. Чоловічі іменування), М. Сенів (Основні способи і засоби ідентибікації жінки в писемних пам'ятках української мови XIV$X V I I \mathrm{~cm}$.). Інші вчені аналізували українські антропоніми на локальному рівні й переважно в певний часовий відрізок, зокрема це демонструють праці 60-80-х років XX ст.: І. Сухомлина (Основи Полтавської ономастики (за матеріалами Полтавських актових книг XVII cm.)), А. Залеського (Спостереження над українськими прізвищами XVII cm.), О. Неділько (Антропонімія північної частини Лівобережної України (друга половина XVII-XVIII cm.)), В. Шевцової (Антропонімія Середньодніпровського Лівобережжя України (на матеріалі середньодніпровських лівобережних пам'яток другої половини XVII - першої половини XVIII cm.)). Найбільш повно і всебічно на регіональному рівні досліджена антропонімія Закарпаття в докторській дисертації П. Чучки (Чучка, 1969), а також у його словнику Прізвища закарпатських українців. Історико-етимологічний словник (Чучка, 2005).

Із 80-х років XX ст. українська антропонімія стає об'єктом аналізу багатьох учених: Г. Бучко (Фамилии Бойковщины в период их становления и в наши дни), Р. Осташа (Украинская антропонимия I половинь XVII века. Мужские личные имена (на материале Реестра Запорожс- 
кого Войска 1649 г.)), М. Демчук (Слов'янські автохтонні особові імена в побуті українців XIV-XVII cm.), С. Панцьо (Антропонімія Лемківщини), О. Добровольської (Лексична база прізвищ, Війська Запорозького, за «Реєстрами» 1649 р.), Б. Близнюк (Сучасні гучульські прізвища в історичному розвитку), Г. Панчук (Антропонімія Опілля), Г. Бачинської (Антропонімія переселенців з Польщі на Тернопільщзну), I. Фаріон (Українські прізвищеві назви Прикарпатської Львівщини наприкінці XVIII - початку XIX століття), Н. Вирсти (Становлення та розвиток антропонімії Покуття).

Найгрунтовніше теоретичне дослідження українських особових назв здійснив М. Худаш у монографії 3 історії української антропонімії. У ній розглянуто українську антропонімію XVI-XVIII ст. - періоду формування та стабілізації сучасної української антропонімійної системи, досліджено власне ім'я як джерело утворення українських прізвищ і прізвиськ, встановлено способи й засоби ідентифікації особи. На основі загального огляду різних способів іменувань людини, засвідчених українськими писемними пам'ятками XVI-XVIII ст., учений стверджує, що «наші предки вже у XVI ст. мали складну систему іменування особи». Ця система не була чимсь виключно замкнутим українським, «основні форми іменувань особи в Україні були успадковані від попередніх століть із давньоруської [...] доби» (Худаш, 1977, с. 107).

Вивченню історичної антропонімії присвячене етимологічне дослідження I. Єфименко Украӥнські прізвищеві назви XVI cm. Дослідниця визначає найпродуктивніші моделі прізвищевих назв і пропонує класифікувати їх за генезисом антропонімооснов:

1) прізвищеві назви, утворені від особових імен;

2) відпрізвиськові прізвищеві назви (тут не уточнено, що розуміється під терміном «прізвисько» - індивідуальне чи спадкове іменування; чи апелятивне означення особи);

3) відойконімні прізвищеві назви;

4) прізвищеві назви спірного походження. Дослідниця наголошує на актуальності етимологічних досліджень, «які допомагають з'ясувати час і місце утворення антропоніма» (Єфименко, 2003, с. 34).

Однією з останніх робіт з історичної антропонімії $є$ монографія С. Медвідь-Пахомової Еволюція антропонімних формул у слов'янських мовах. У праці подано джерела реконструкції праслов’янської антропо- 
системи, здійснено огляд класифікацій антропонімних формул у слов’янській історичній антропоніміці, детально описано процес розвитку антропонімів у слов'янських мовах (Медвідь-Пахомова, 2012).

Найважливішим елементом антропонімної формули є прізвище. Дослідження українських прізвищ розпочалося в останні два десятиліття XIX ст. Була надрукована розвідка А. Степовича Заметки о происхождении малорусских фамилий, що стала першою опублікованою працею про українські прізвища (Степович, 1882). Через деякий час у січневій книжці «Киевской старины» з'явилася стаття М. Сумцова Малорусские фамильные прозвания, у якій автор робить спробу встановити основні засоби словотвору українських прізвищ і класифікувати їх за семантикою основ (Сумцов, 1885). Згодом виходить із друку робота В. Ястребова Малороссийские прозвища Херсонской губернии (Ястребов, 1893), а в «Житті і слові» надруковані уваги В. Охримовича Про сільські прозвищза (Охримович, 1895).

Процес формування українських прізвищ детально аналізує у своїй праці Причинки до украӥнської ономастики І. Франко. Вчений дає грунтовну характеристику трьох структурних типів антропонімів, що вживаються у функції прізвищ:

1) прізвища у формі родового відмінка однини (Onyśko Krywoho syn, Hrycz Nagornego);

2) форми прізвищ nom. sing. здрібнілого neutrum на -я (-ьa) і форми nom. plur. здрібнілого neutr. на -ята, -ьата (Процев'я, Романча; Проиев'ята, Романчата);

3) прізвища, які в nom. sing. є граматично gen. plur. neutr. (Androwiąt, Wankowiąt, Hryckowią) (Франко, 1986, сc. 396-409).

I. Франко наголошує на тому, що пізнання прізвищ та імен дає нам інформацію про суспільний та економічний лад українського села, про еволюцію форм землеволодіння. В прізвищах закріплюється зв'язок поколінь між собою, історія народу (Франко, 1986, сс. 423-424).

Одним із найцінніших досліджень для вивчення прізвищ $є$ монографія М. Худаша 3 історії української антропонімії. У ній автор на величезному фактичному історичному матеріалі прослідковує функціонування додаткових, крім власного імені, окреслень особи. Відштовхуючись при класифікації матеріалу від особливостей використаних у писемних пам’ят- 
ках лексичних засобів для ідентифікації особи, вчений ділить способи іменувань людей у пам'ятках XVI-XVIII ст. на три категорії:

1) власне антропонімійні іменування (іменування, які базуються тільки на антропонімійному матеріалі, на самих лише особових назвах у повному розумінні цього терміна);

2) апелятивні іменування (іменування, які дають апелятивне окреслення людини);

3) мішані, або антропонімійно-апелятивні іменування (іменування, у яких крім особових назв людини, як допоміжний засіб ідентифікації, використовуються ще й відповідні апелятивні окреслення) (Худаш, 1977, с. 110).

М. Худаш стверджує, що до початку XIX ст. прізвища основної частини населення України ще не були сформовані. Особові назви періоду їх невнормованого вживання, які документально ніби виконували роль прізвищ, служили допоміжним засобом ідентифікації особи й мали зовнішню форму прізвищ, учений умовно називає «прізвищевими назвами», вкладаючи в цей термін поняття «іменування людини назвою типу прізвища», і розглядає його як тимчасовий і суто робочий (Худаш, 1977, сс. 99-100). Проте цей термін закріпився в науковій літературі й використаний у багатьох дослідженнях (Блажчук, 2008; Близнюк, 1997; Кравченко, 2004; Осташ, 1991; Панчук, 1999; Рульова, 2004; Шеремета, 2002).

Словотвірна структура особових назв, засвідчених пам'ятками української мови XIV-XV ст., проаналізована в роботі Л. Гумецької Нарис словотворчої системи украӥнської актової мови XIV-XV cm. (Гумецька, 1958).

Способи й засоби ідентифікації особи в пам’ятках XVI ст. досліджує в своїй монографії Р. Керста. Вчена зазначає, що в документах XVI ст. попадаються різноманітні й довільні способи іменувань. В одному випадку особа іменується виключно християнським іменем, повністю адаптованим українською мовою, у другому - вказівкою на заняття або службове становище, у третьому - до власного імені додається означення із вказівкою на походження іменованої особи з тієї чи іншої місцевості. Крім власного імені, іменована особа може називатися за певними рисами своєї зовнішності, за іменем або заняттям батька, на підставі певних відношень до конкретних людей. Такі різнотипні способи іменування трапляються навіть в одному і тому ж документі (Керста, 1984, с. 7). 
Українська антропонімія пам'яток XVII ст. представлена в дослідженні Ю. Карпенка Реєстри війська Запорозького і проблеми постання українських прізвищ (Карпенко, 1994).

Комплексно досліджена українська антропонімія на прикладі Закарпаття у докторській дисертації П. Чучки Антропонімія Закарпаття (Чучка, 1969).

Системне наукове вивчення українських прізвищ припадає на другу половину XX ст. Зібрано й проаналізовано прізвища окремих історико-етнографічних регіонів України, зокрема історичний антропонімікон: Лемківщини (С. Панцьо), Верхньої Наддністрянщини (І. Фаріон), Буковинської Наддністрянщини (Л. Тарновецька), Лівобережної України (С. Глущик), Житомирщини (Л. Ящук); давні та сучасні прізвища: Закарпаття (П. Чучка), Бойківщини (Г. Бучко), Гуцульщини (Б. Близнюк), Опілля (Г. Панчук), Лубенщини (Л. Кравченко), Північної Тернопільщини (С. Шеремета), Західного Поділля (Н. Рульова), Нижньої Наддніпрянщини (І. Ільченко), Уманщини (Ю. Блажчук), Розточчя (О. Марочкіна), Покуття (Н. Вирста); сучасні прізвища: Південно-Східної України (В. Познанська); Північного Степу України (Т. Марталога); Дніпровського Припоріжжя (І. Корнієнко), Північної Донеччини (Н. Булава), Середньої Наддніпрянщини (Ю. Бабій), Центральної та Східної Донеччини (Ю. Новікова). Окремо досліджено прізвища українських переселенців з Польщі (Г. Бачинська).

Після появи Довідника украӥнських прізвищ, Ю. Редька (1969 р.) пожвавилася робота в галузі ономастичної лексикографії: вийшла низка нових словників українських прізвищ різних регіонів України: словник прізвищ степової України (2000р.) (В. Горпинич); етимологічний словник українських прізвищевих назв Прикарпатської Львівщини кін. XVIII поч. XIX ст. (2001 р.) (I. Фаріон); практичний словозмінно-орфографічний словник прізвищ на матеріалі Чернівеччини (2002р.) (Н. Бабич); словник українських прізвищевих назв XVI ст. (2003 p) (I. Єфименко); словник прізвищ Дніпровського Припоріжжя (2003р.) (В. Горпинич, I. Корнієнко); словник прізвищ Правобережного Степу (2005 р.) (В. Горпинич, Т. Тимченко); словник оригінальних козацьких прізвищ (2005р.) (В. Буркат); словник імен та прізвищ Гуляйпільщини (2007р.) (В. Горпинич); словник сучасних прізвищ Запорізької Приазовщини (2009р.) (П. Стехна). На жаль, більшість із зазначених словників не несуть ніякої ономастичної інформації про прізвища, а деякі - це лише списки навіть не в алфавітному порядку (тобто це просто матеріал). 
3 великої кількості друкованих лексикографічних видань на особливу увагу всіх тих, хто цікавиться антропонімією, заслуговує історико-етимологічний словник прізвищ закарпатських українців (2005р.) (Чучка, 2005), у якому подано всі прізвища, що функціонували на території Закарпатської області в перші повоєнні роки і тепер функціонують як прізвища корінних українців (понад 11 500). Крім правописних, орфоепічних та граматичних настанов, біля прізвища наводяться нинішня його географія побутування з точністю до села, перші фіксації прізвищевої назви в давніх документах Карпатського регіону, дані про соціальний статус засновника роду. Статті завершуються етимологічною розвідкою щодо походження прізвища, його початкової форми та допрізвищевого значення. Справжньою знахідкою для філологів, істориків, народознавців $€$ передмова до словника, у якій розглядаються загальні питання теорії прізвища, історія становлення цього феномена і специфіка функціонування родових назв в Українських Карпатах; аналізуються мовний і правовий статуси прізвища, глобальні національні, регіональні ознаки прізвищетворчих формантів, принципи етимологізування, правопис, вимова і відмінювання прізвищ (Чучка, 2005).

Однією з останніх і чи не найголовнішою лексикографічною працею на теренах усієї України є Словник сучасних українських прізвищ Ю. Редька (у 2-х томах, 2007 р.), укладений автором ще в 1976 р., а виданий посмертно за підтримки НТШ в Америці. Словник охоплює 15000 прізвищ. На сьогодні це єдина праця, у якій зібрані антропоніми не одного якогось регіону, а всієї території України. Словник не охоплює всіх прізвищ України, але в ньому є локалізація; вона, може, й не повна (на це вказують критерії збору матеріалу), але все ж таки дає серйозну інформацію (Редько, 2007). У 2008 р. вийшла друком монографія Антропонімія Закарпаття, що містить повний текст докторської дисертації П. Чучки, захищеної 1969 р. в Київському державному університеті ім. Т. Шевченка, а також рецензії офіційних опонентів (Чучка, 1969). У 2011 році був надрукований словник П. Чучки Слов'янські особові імена украӥнців - перший в історії української ономастики етимологічний словник, у якому описано особові імена українців (Чучка, 2011).

Готується до друку словник українських імен (за матеріалами «Реєстрів») Р. Осташа, окремі частини якого вже опубліковані.

Сьогодні продовжуються пошуки нових аспектів вивчення антропонімів, тривають дослідження регіональної антропонімії в синхронії 
та діахронії, розробляються основні теоретичні засади ономастичних студій, розвивається фольклорна та літературна ономастика, значна увага приділяється проблемі перекладу і транслітерації антропонімів у літературних творах.

\section{Лексична база прізвищ та проблеми їх класифікації}

Незважаючи на значні здобутки, в українській ономастиці не до кінця вирішеною є проблема формування, становлення та остаточної стабілізації українських прізвищ. Стосовно цієї проблеми вчені висловлювали різні думки. Так, Л. Гумецька, досліджуючи антропонімію української актової мови XIV-XV ст., виділяє різні типи власних особових назв: прізвисько, прізвище, ім'я та по батькові в сучасному розумінні (Гумецька, 1958). На думку І. Сухомлина, відіменні прізвища виникли і сформувалися ще в XIII-XIV ст., вони творилися людьми від розмовних форм імені й передавалися від покоління до покоління часто без лексико-морфологічних змін (Сухомлин, 1964, с. 89).

I. Франко вважав, що початок закріплення прізвищ відбувся в Україні в середині XVII ст., коли Петро Могила «наказав православному духовенству вести метрики вроджених, зашлюблених і померших». У Галичині це зробив єпископ Йосип Шумлянський, видавши у 1687 р. Метрику. Одначе, на думку I. Франка, ці метрики не мають для нас ніякої вартості, оскільки священники записували лише хресні імена, ігноруючи родові й усякі інші прізвища. Тільки від 1772 р., коли Галичина увійшла до Австрії, датується правильне ведення реєстрів усієї людності, а отже, й закріплення тодішніх родових прізвищ (Франко, 1986, с. 395).

М. Худаш відзначає, що й до початку XIX ст. прізвища основної частини населення України ще не були сформовані. У своїй монографії 3 iсторіі української антропонімї вчений робить висновки, що до початку ХІХ ст. практика ідентифікації особи в Україні входила в сферу звичаєвого права. Крім власного імені, часто вживаного в різних можливих його формах, використовували назви, які особа мала в побуті. Спадкове вживання особових назв типу прізвищ не було обов'язковим, а жінки, навіть вищих суспільних верств, іменувалися переважно відносно батька, чоловіка, брата або комбіновано. Патронімні й матронімні особові назви та назви осіб за професією - це не спадкові, а прямі назви по батькові чи матері, 
або апелятиви, що вказують на заняття конкретної особи; відтопонімні назви часто ще вказують на місце походження чи проживання особи. Невнормованість і довільне вживання особових назв в Україні існували, допоки не були запроваджені кодифіковане право і практика ідентифікації особи, введені державою наприкінці XVIII ст. від патенту цісаря Йосипа II, а згодом на початку XIX ст. від патенту цісаря Франца I. Через деякий час у всій Австрійській імперії, до складу якої входила Галичина, був запроваджений «Загальний цивільний кодекс», який закріпив уживані особові назви як спадкові прізвища. На іншій території України, що входила до Російської імперії, таке унормування почалося пізніше, коли у 1826 р. в усій Росії був запроваджений цивільний кодекс. Отже, на думку М. Худаша, про українські прізвища в сучасному розумінні цього терміна можна говорити від 30-х років ХІХ ст. (Худаш, 1977, сс. 96-97). Саме цей час вважають вирішальним у становленні і стабілізації українських прізвищ.

Подібні припущення висловлюють і інші дослідники. Так, О. Неділько процес закріплення прізвищ багатших верств населення відносить до 30-х років XVII ст., а простих людей - до другої половини XVII ст. (Недилько, 1969, с. 6). На початку XVII ст., відзначає В. Франчук, спостерігаються лише початкові риси у творенні прізвищ основної маси населення України - селянства (Франчук, 1965, с. 256). Ю. Редько, автор довідника українських прізвищ, указує на те, що українські прізвища, особливо селянські, переважно формувалися приблизно з XVII ст. і закріпилися в документах тільки наприкінці XVIII ст. (Редько, 1968, с. 38).

Дискусійним і невирішеним залишається питання класифікації прізвищ, що $є$ дуже важливим у процесі вивчення та аналізу антропонімів. Від ступеня наукової достовірності класифікації, зауважує М. Худаш, «залежить не тільки економність, структурно-композиційна чіткість і раціональність дослідження, а і його ефективність та результативність». Тому будь-яка класифікаційна схема має максимально забезпечувати можливість розгляду досліджуваного об'єкта в найрізноманітніших його проявах і водночас не допускати фактів двозначності, невизначеності, суб’єктивізму (Худаш, 1980, с. 101). Численні спроби слов’янських ономастів створити єдину класифікацію антропонімів, у т. ч. прізвищ, поки що не призвели до якоїсь єдиної класифікаційної схеми. В сучасній слов’янській антропоніміці і не тільки, зазначає П. Чучка, існують різні аспекти аналізу прізвищ: словотвірний, етимологічний, фонетико-морфологічний 
і лексико-семантичний. На думку вченого, поєднання або просто змішування цих аспектів ономастами, навіть дуже видатними, зумовлює суперечності в питаннях класифікації та аналізу прізвищ (Чучка, 1969, сс. 273-274). Оскільки кожен аспект має свої завдання, проблематику і специфіку, а поєднати їх в одному дослідженні важко, то П. Чучка розглядає прізвища Закарпаття за кожним аспектом окремо: словотвір, семантика твірних основ, етимологія (Чучка, 1969, с. 274). В українській і слов’янській антропоніміці дослідники сучасних прізвищ (М. Бірила, Б. Близнюк, Г. Бучко, Л. Кравченко, Г. Панчук, А. Суперанська та ін.) аналізують свій матеріал, зазвичай, у двох аспектах: за лексико-семантичними ознаками основ і за структурно-граматичними та словотвірними характеристиками прізвищ.

Важливим для аналізу прізвищ, як зауважує П. Чучка, є те, з чого постало кожне окреме прізвище, якою була допрізвищева семантика цього слова, які саме семантичні пласти лексики послужили основою прізвищ. Відомо, що в різних народів прізвищами стають не одні й ті ж слова. Неоднакове використання різних пластів лексики при творенні прізвищ $є$ однією із специфічних особливостей кожної національної антропонімії. Отже, первісна семантика прізвищ має велику вагу (Чучка, 1969, с. 385).

На східнослов'янському мовному грунті семантичну класифікацію прізвищ пропонували М. Бірила, Ю. Редько та О. Трубачов. Кожен з цих дослідників робив це по-іншому. Так, М. Бірила виділяв дві групи іменувань: прізвища від християнських особових імен та прізвища від апелятивних прізвиськ. У другій групі вчений виокремлював прізвища, утворені від особових і неособових апелятивів. В окрему групу М. Бірила зараховував прізвища іншомовного походження та прізвища, що мають невиразну за походженням і значенням твірну основу (Бірыла, 1963, сc. 7-12), цим він, на думку П. Чучки, поєднував два суперечливі принципи - семантичний та етимологічний (Чучка, 1969, с. 387), що зашкодило авторській класифікації.

Не до кінця опрацьованою є також класифікація Ю. Редька. Вчений ділить усі прізвища за семантикою їх твірних основ на чотири основні групи:

«прізвища, утворені від особових імен», «прізвища і топонімічні назви», 
«прізвища, утворені за соціальною приналежністю або від назви постійного заняття»,

«прізвища, утворені за індивідуальними ознаками перших носіїв» і п’яту додаткову (Редько, 1966, сс. 9-80):

«інші шляхи виникнення прізвищ».

Як зауважує П. Чучка, виділення груп у цій класифікації здійснено несподівано, з різних засад (Чучка, 1969, с. 387).

О. Трубачов вважав, що прізвища різних народів світу можна прокласифікувати більш-менш єдино, поділивши їх на такі чотири групи:

1) прізвища з хресних імен,

2) прізвища з назв професій,

3) прізвища від назв поселень (назва села, передмістя) та

4) прізвиська в ролі прізвищ (Трубачев, 1968, с. 12).

П. Чучка ділить усі прізвища Закарпаття за семантикою основ на три категорії:

1) прізвища відіменні («прізвища, в основі яких лежать імена»);

2) прізвища відапелятивні («прізвища, в основі яких лежать апелятиви»);

3) прізвища відтопонімні («прізвища, в основі яких лежать топоніми»).

Такий поділ сучасних прізвищ, наголошує вчений, пов'язаний з певними труднощами.

До відіменних, наприклад, доводиться зараховувати не лише так звані первинні утворення зразка Васи́л', Васил'úó, Вас'кó, Вас’ó, які безпосередньо походять від імен, але й вторинні та третинні утворення на зразок Андрійка́нич, Васили́шин, Грииако́вич, Данку́линеи', Павл'учо́к, хоч останнім до відіменних насправді досить далеко, оскільки вони безпосередньо від імен не походять, а утворені фактично від новіших андронімічних та патронімічних прізвиськ типу Андрійка́н'a, Васили́ха, Гриия́к, Данку́л’а, Павл'ýк (Чучка, 1969, с. 388).

Багато відіменних прізвищ, зокрема ті, що походять від дохристиянських імен, П. Чучка відносить до апелятивів, оскільки повного реєстру язичницьких імен немає, а надійних критеріїв розмежування давньої слов'янської лексики на апелятиви та власні особові імена ще не вироблено. Відтопонімні прізвища часом важко відрізнити від звичайних відіменних прізвищ. «Взагалі, - наголошує вчений, - відтопонімні прізвища можна 
6 і не виділяти в окрему групу, а розглядати їх у межах відапелятивних, як такі, що походять від звичайних катойконімів [...] чи відтопонімних прикметників» (Чучка, 1969, сс. 388-389).

М. Худаш у праці До питання класифікації прізвищевих назв $X I V-X V I I I \mathrm{~cm}$. виділив три основні групи найменувань, що використовувалися як додаткові іменування при особовому імені до остаточної стабілізації прізвищ: апелятивні, апелятивно-антропонімні і власне антропонімні. Дослідник називає конкретні групи лексики, що входять до кожної групи найменувань. До «власне антропонімійних назв» він уже без подальшого поділу включає всі ті додаткові до особового імені назви, які оформлені посесивними та патронімними суфіксами (Худаш, 1980, сс. 135-160). Саме цією класифікацією при лексичному аналізі прізвищ часто користуються дослідники регіональної антропонімії, при цьому нерідко розширюючи і доповнюючи класифікаційні розряди аналізованих ними прізвищ. Так, Б. Близнюк, досліджуючи антропонімію Гуцульщини, виділяє прізвища, що походять від непоширених у наш час раритетних, говіркових апелятивів, а також індивідуальних випадкових апелятивних утворень (Гуцайло, Кликайло, Кандибайло, Скидан, Штиркало) (Близнюк, 1997). Не завжди етимони прізвищ $є$ семантично однозначними лексемами. Мотивовані такими основами прізвища більшість ономастів пропонують ідентифікувати як окремий семантичний тип, називаючи їх кожен по-своєму: «неясні і сумнівні прізвища» (Г. Бачинська), «прізвища спірної мотивації» (Л. Кравченко), «полісемантичні прізвища» (Н. Булава), «прізвища з непрозорою семантикою», «полісемантичні прізвищеві побудови» (Ю. Бабій).

Отже, в ході дослідження визначено основні етапи формування та закріплення прізвищ як офіційних родових знаків. Розглянуто, зокрема, процеси, які сприяли становленню та стабілізації української прізвищевої системи, проаналізовано лексичну базу прізвищ, окреслено найпродуктивніші групи лексики, яка послужила основою для сучасних українських прізвищ. Вказано на проблеми класифікації українських прізвищ, а також представлено науковий досвід щодо поділу прізвищ за мотивувальними ознаками та способом творення.

Загалом українські вчені мають вже значні здобутки у вивченні антропонімії, однак найповніше вона досліджена лише регіонально. На жаль, на сьогодні немає єдиного реєстру українських прізвищ. 
Перспективи подальших досліджень вбачаємо у виявленні нерозривного зв'язку ономастики з іншими лінгвістичними та суспільними науками (правознавством, історією, політологією, етнографією, психологією, соціологією, естетикою), в необхідності розвитку їі в теоретичному, порівняльно-описовому, історичному, поетично-літературному напрямках. Результати вивчення історичної антропонімії $€$ неоціненним джерелом для дослідження різних розділів мовознавства, але передусім історії мови та діалектології, оскільки в прізвищах нерідко зберігається лексика, яка вже вийшла з ужитку.

\section{Бібліографія}

Бірыла, М. (1963). Беларускія антрапанімічныя назвы у іх адносінах да антрапанімічных назваў іншых славянскіх моў. Выд. Акадэміі навук БССР.

Блажчук, Ю. (2008). Антропонімія Уманщини XVII - початку XXI cm. [Unpublished summary of doctoral dissertation]. Національний педагогічний університет ім. М. П. Драгоманова.

Близнюк, Б. (1997). Сучасні гуиульські прізвищза в історичному розвитку [Unpublished summary of doctoral dissertation]. Львівський державний університет ім. І. Франка.

Гумецька, Л. (1958). Нарис словотворчої системи української актової мови XIV-XV cm. Видавництво АН УРСР.

Енциклопедія українознавства в 11 томах. (1993-2003). НТШ.

Єфименко, I. (2003). Українські прізвищеві назви XVI cm. НАН України, Інститут української мови.

Карпенко, Ю. (1994). Реєстри Війська Запорізького і проблема постання українських прізвищ. In О. Карпенко (Ed.), Питання історичної ономастики Украӥни (pp. 182-248). Наукова думка.

Керста, Р. (1984). Українська антропонімія XVI ст.: Чоловічі іменування. Наукова думка. Кравченко, Л. (2004). Прізвища Лубенщзин. Факт.

Медвідь-Пахомова, С. (2012). Еволюція антропонімних формул у слов'янських мовах. Видавництво Олександри Гаркуші.

Недилько, О. (1969). Антропонимия северной части Левобережной Украины (вторая половина XVII-XVIII вв.) [Unpublished summary of doctoral dissertation]. Киевский государственный педагогический институт им. Горького.

Осташ, Р. (1991). Власні особові імена у функції прізвищевих назв. In P. Керста (Ed.), Українська лексика в історичному та ареальному аспектах (pp. 155-163). Наукова думка. 
Охримович, В. (1895). Знадоби до пізнання народних звичаїв і поглядів правних. Житє і слово, 3, 302-307.

Панчук, Г. (1999). Антропонімія Опілля [Unpublished summary of doctoral dissertation]. Тернопільський державний педагогічний університет ім. Володимира Гнатюка.

Редько, Ю. (1966). Сучасні українські прізвища. Наукова думка.

Редько, Ю. (1968). Довідник українських прізвищ. Радянська школа.

Редько, Ю. (2007). Словник сучасних украӥнських прізвищ: У 2-х томах. Наукове товариство ім. Т. Шевченка.

Рульова, Н. (2004). Антропонімія Західного Поділля кіния XVIII-XX cm. [Unpublished summary of doctoral dissertation]. Прикарпатський університет ім. Василя Стефаника.

Сімович, В. (1929). Українські йменники чоловічого роду на -о в історичному розвитку й освітленні. In В. Сімович (Ed.), Праці Украӥнського високого педагогічного інституту ім. Михайла Драгоманова у Празі (Vol. 1, pp. 305-369). Academia Paedagogica Ucrainensis.

Степович, А. (1882). Заметки о происхождении и склонении малорусских фамилий. Филологические записки, 6, 1-7.

Сумцов, Н. (1885). Малорусские фамильные прозвания. Киевская старина, 11, 215-228.

Сухомлин, I. (1964). Основи полтавської ономастики (за матеріалами Полтавських актових книг XVII cm.) [Unpublished summary of doctoral dissertation]. Харків.

Трубачев, О. (1968). Из материалов для этимологического словаря фамилий России. Этимология, 1966, 3-53.

Франко, I. (1986). Причинки до української ономастики. In I. Франко, Зібрання творів (Vol. 36, pp. 391-426). Наукова думка.

Франчук, В. (1965). Українські особові назви XVII ст. In К. Цілуйко (Ed.), Питання ономастики (Матеріали II Республіканської наради з питань ономастики) (рр. 252-257). Наукова думка.

Худаш, М. (1977). 3 історії української антропонімії. Наукова думка.

Худаш, М. (1980). До питання класифікації прізвищевих назв XIV-XVIII ст. In Д. Г. Гринчишин et al. (Eds.), 3 історії украӥнської лексикологіï (pp. 96-160). Наукова думка.

Чучка, П. (1969). Антропонімія Закарпаття [Unpublished post-doctoral dissertation]. Київський державний університет ім. Т. Шевченка.

Чучка, П. (2005). Прізвища закарпатських українців: Історико-етимологічний словник. Світ.

Чучка, П. (2011). Слов’янські особові імена украйнців: Історичний етимологічний словник. Ліра.

Шеремета, С. (2002). Антропонімія північної Тернопільщини [Unpublished summary of doctoral dissertation]. Прикарпатський університет ім. Василя Стефаника.

Ястребов, В. (1893). Малорусские прозвища Херсонской губернии. Типография В. В. Кирхнера. 


\section{Bibliography (Transliteration)}

Biryla, M. (1963). Belaruskiia antrapanimichnyia nazvy ŭ ikh adnosinakh da antrapanimichnykh nazvaŭ inshykh slavianskikh moŭ. Vyd. Akadèmii navuk BSSR.

Blazhchuk, I. (2008). Antroponimiia Umanshchyny XVII - pochatku XXI st. [Unpublished summary of doctoral dissertation]. Natsional'nyı̆ pedahohichnyı̆ universytet im. M. P. Drahomanova.

Blyzniuk, B. (1997). Suchasni hutsul's'ki prizvyshcha v istorychnomu rozvytku [Unpublished summary of doctoral dissertation]. L'vivs'kyı̌ derzhavnyı̆ universytet im. I. Franka.

Chuchka, P. (1969). Antroponimiia Zakarpattia [Unpublished post-doctoral dissertation]. Kyïvs'kyĭ derzhavnyĭ universytet im. T. Shevchenka.

Chuchka, P. (2005). Prizvyshcha zakarpats'kykh ukraïntsiv: Istoryko-etymolohichnyi slovnyk. Svit.

Chuchka, P. (2011). Slov'ians'ki osobovi imena ukraïntsiv: Istorychnyi etymolohichnyi slovnyk. Lira.

Entsyklopediia ukraïnoznavstva $v 11$ tomakh. (1993-2003). NTSh.

Franchuk, V. (1965). Ukraïns'ki osobovi nazvy XVII st. In K. TSiluǐko (Ed.), Pytannia onomastyky (Materialy II Respublikans'koï narady z pytan' onomastyky) (pp. 252-257). Naukova dumka.

Franko, I. (1986). Prychynky do ukraïns'koï onomastyky. In I. Franko, Zibrannia tvoriv (Vol. 36, pp. 391-426). Naukova dumka.

Humets'ka, L. (1958). Narys slovotvorchoï systemy ukraïns'koï aktovoï movy XIV-XV st. Vydavnytstvo AN URSR.

IAstrebov, V. (1893). Malorusskie prozvishcha Khersonskoĭ gubernii. Tipografiia V. V. Kirkhnera.

IEfymenko, I. (2003). Ukraïns'ki prizvyshchevi nazvy XVI st. NAN Ukraïny, Instytut ukraïns'koï movy.

Karpenko, I. (1994). Reiestry Viǔs'ka Zaporiz'koho i problema postannia ukraïns'kykh prizvyshch. In O. Karpenko (Ed.), Pytannia istorychnoï onomastyky Ukraïny (pp. 182-248). Naukova dumka.

Kersta, R. (1984). Ukraïns'ka antroponimiia XVI st.: Cholovichi imenuvannia. Naukova dumka.

Khudash, M. (1977). Z istorii ukraïns'koï antroponimii. Naukova dumka.

Khudash, M. (1980). Do pytannia klasyfikatsiï prizvyshchevykh nazv XIV-XVIII st. In D. H. Hrynchyshyn et al. (Eds.), Z istoriï ukraïns'koï leksykolohï (pp.96-160). Naukova dumka.

Kravchenko, L. (2004). Prizvyshcha Lubenshchyny. Fakt.

Medvid'-Pakhomova, S. (2012). Evoliutsiia antroponimnykh formul u slov'ians'kykh movakh. Vydavnytstvo Oleksandry Harkushi.

Nedil'ko, O. (1969). Antroponimiia severnoŭ chasti Levoberezhnoŭ Ukrainy (vtoraia polovina XVII-XVIII vv.) [Unpublished summary of doctoral dissertation]. Kievskiŭ gosudarstvenny̌ pedagogicheskiǔ institut im. Gor'kogo.

Okhrymovych, V. (1895). Znadoby do piznannia narodnykh zvychaïv i pohliadiv pravnykh. ZHytie i slovo, 3, 302-307. 
Ostash, R. (1991). Vlasni osobovi imena u funktsiï prizvyshchevykh nazv. In R. Kersta (Ed.), Ukrä̈n'ka leksyka $v$ istorychnomu ta areal'nomu aspektakh (pp. 155-163). Naukova dumka.

Panchuk, H. (1999). Antroponimiia Opillia [Unpublished summary of doctoral dissertation]. Ternopil's'kyĭ derzhavnyı̆ pedahohichnyĭ universytet im. Volodymyra Hnatiuka.

Red'ko, I. (1966). Suchasni ukraïns'ki prizvyshcha. Naukova dumka.

Red'ko, I. (1968). Dovidnyk ukraïns'kykh prizvyshch. Radians'ka shkola.

Red'ko, I. (2007). Slovnyk suchasnykh ukraïns'kykh prizvyshch: U 2-kh tomakh. Naukove tovarystvo im. T. Shevchenka.

Rul'ova, N. (2004). Antroponimiia Zakhidnoho Podillia kintsia XVIII-XX st. [Unpublished summary of doctoral dissertation]. Prykarpats'kyı̆ universytet im. Vasylia Stefanyka.

Sheremeta, S. (2002). Antroponimiia pivnichnoï Ternopil'shchyny [Unpublished summary of doctoral dissertation]. Prykarpats'kyı̆ universytet im. Vasylia Stefanyka.

Simovych, V. (1929). Ukraïns'ki řmennyky cholovichoho rodu na -o v istorychnomu rozvytku i osvitlenni. In V. Simovych (Ed.), Pratsi Ukraïns'koho vysokoho pedahohichnoho instytutu im. Mykhaŭla Drahomanova u Prazi (Vol. 1, pp. 305-369). Academia Paedagogica Ucrainensis.

Stepovich, A. (1882). Zametki o proiskhozhdenii i sklonenii malorusskikh familir. Filologicheskie zapiski, 6, 1-7.

Sukhomlyn, I. (1964). Osnovy poltavs'koï onomastyky (za materialamy Poltavs'kykh aktovykh knyh XVII st.) [Unpublished summary of doctoral dissertation]. Kharkiv.

Sumtsov, N. (1885). Malorusskie famil'nye prozvaniia. Kievskaia starina, 11, 215-228.

Trubachev, O. (1968). Iz materialov dlia ètimologicheskogo slovaria familiı̆ Rossii. Étimologiia, 1966, 3-53.

\section{Main Trends in the Study of Ukrainian Surnames (Late Seventeenth - Early Twenty-First Centuries): I. The Achievements of Ukrainian Onomasticians}

\section{Summary}

This article analyses main trends in the study of Ukrainian surnames from the period between the late seventeenth and the early twenty-first centuries. It points out the topicality of research on regional anthroponymy and its contribution to the development of studies on dialects, lexis, word formation and 
other issues in linguistics. Proper names contain a wealth of linguistic and historical information on realities of a nation or a particular region. The analysed material demonstrates that scholars investigating Ukrainian surnames have devoted considerable attention to the formation and development of the Ukrainian anthroponymic system, the functioning of anthroponyms in language, and the origin and semantics of personal names. They have identified the main stages in the formation of Ukrainian surnames and outlined the development of their role as a sign common to all members of a family, focusing in particular on the processes that have fostered the formation and development of the Ukrainian surname system. They have also examined the lexical basis of surnames, and identified the most productive lexical groups in this regard. The article presents the state of research on the classification of Ukrainian surnames according to their motivation features and means of their formation. It also sketches the prospects of further studies on Ukrainian anthroponomy. It points out that as yet there is no full register of Ukrainian surnames, and that some of the materials collected in particular regions have only been presented in dissertations and are often kept in private files of the researchers.

\title{
Główne kierunki badań nad ukraińskimi nazwiskami (koniec XVII - początek XXI wieku): I. Dorobek ukraińskich onomastów
}

\author{
Streszczenie
}

Artykuł dotyczy analizy głównych kierunków w badaniach nad ukraińskimi nazwiskami z okresu od końca XVII do początków XXI wieku. Wskazano na aktualność badań w zakresie antroponimii regionalnej, które w znacznym stopniu przyczyniają się do rozwoju dialektologii, leksykologii, derywatologii i innych gałęzi językoznawstwa. Nazwy osobowe najpełniej odzwierciedlają językowe i historyczne realia dawnego życia całego narodu lub określonego regionu. Przeanalizowany materiał pozwala stwierdzić, że badając nazwiska ukraińskie, naukowcy zwracają dużą uwagę na tworzenie i rozwój narodo- 
wego systemu antroponomicznego, funkcjonowanie antroponimów w języku, pochodzenie i semantykę nazw osobowych. Badacze określili główne etapy kształtowania się i stabilizowania nazwisk jako oficjalnych znaków rodowych, zwracając uwagę zwłaszcza na procesy, które przyczyniły się do powstania i stabilizacji ukraińskiego systemu nazwisk. Zbadali także leksykalną bazę nazwisk i ustalili najbardziej produktywne grupy leksykalne stanowiące podstawę słowotwórczą współczesnych nazwisk ukraińskich. W artykule omówiono stan badań w zakresie podziału nazwisk według cech motywacyjnych i środków ich tworzenia. Przedstawiono perspektywy dalszych badań nad antroponimią ukraińską. Autorki zwracają uwagę na brak całościowego indeksu ukraińskich nazwisk i na to, że materiały zebrane w pewnych regionach zostały przedstawione tylko w dysertacjach i często są przechowywane wyłącznie w prywatnych kartotekach.

Keywords: surname; first name; anthroponymy; onomastics; surname suffix; etymon

Słowa kluczowe: nazwisko; imię; antroponimia; onomastyka; przyrostek nazwiska; etymon

(1) Nataliya Vyrsta, Ternopil Volodymyr Hnatiuk National Pedagogical University, Ternopil, Ukraine ORCID: https://orcid.org/0000-0001-9707-3406

Correspondence: nataljabahrij@ukr.net

(2) Nataliya Rokitska, Ternopil Volodymyr Hnatiuk National Pedagogical University, Ternopil, Ukraine ORCID: https://orcid.org/0000-0001-9192-6113

Correspondence: ndaniw@ukr.net

Authors' contribution: Both authors contributed to the preparation of this original text. The following declarations about particular authors' contribution to the research have been made: concept of the study - first author; data analysis - second author; drafting the manuscript - both authors.

The preparation of this article was self-financed by the authors.

Competing interests: The authors have declared that they have no competing interests. 